\title{
Characterization of glycoconjugates in the bovine endometrium and chorion by lectin histochemistry
}

\author{
L. Munson*, J. J. Kao and D. H. Schlafer \\ Department of Pathology, New York State College of Veterinary Medicine, Cornell University, \\ Ithaca, NY 14853, USA
}

\begin{abstract}
Summary. Lectin binding patterns were examined on normal bovine endometrium and bovine placentomes during four stages of pregnancy using 13 biotinylated lectins. Lectin binding intensity increased in early pregnancy for many lectins, whereas binding to fucosyl residues decreased. Persistence of strong lectin binding later in pregnancy usually was limited to the arcade and intercotyledonary trophoblastic cells. Binding of some lectins to cell surfaces was prominent, particularly in early pregnancy. A few lectins were excellent markers for binucleate trophoblastic cells. These distinctive surface and binucleate cell binding patterns on placentomes and endometrial epithelium are useful markers of trophoblastic cell-endometrial epithelial cell surface interactions and of binucleate cell differentiation.
\end{abstract}

Keywords: lectin; placentome; cattle; trophoblast; endometrium

\section{Introduction}

The establishment and maintenance of contact between trophoblastic cells and endometrial epithelial cells are essential for pregnancy in species with epitheliochorial placentation. These processes are likely to involve glycosylated membrane proteins, since most cell-cell adhesion occurs through carbohydrate molecules (Brandley \& Schnaar, 1986). Cell adhesion molecules are a family of membrane glycoproteins that regulate recognition and attachment between cells (Edelman, 1986) and attachment of cells to substratum (Knudsen et al., 1981; Damsky et al., 1982). Cell adhesion molecules play a major role in embryogenesis (Edelman, 1984; Feizi, 1985), including the attachment of the trophoblast to the endometrium (Richa et al., 1985).

The rich carbohydrate content of cell adhesion molecules permits their general localization within tissues by lectin binding (Alroy et al., 1988). Lectins are plant-derived proteins which bind specifically but non-immunologically to saccharides. They have been used to define the types and distribution of glycoconjugates on normal embryonic and adult cells (Laitinen et al., 1987; Alroy et al., 1988) and have been applied to studies of alterations in cell growth and differentiation in metaplastic and neoplastic conditions (Alroy et al., 1982, 1986; Hsu \& Ree, 1983; Orgad et al., 1984; Castagnaro et al., 1987). The avidity of lectin binding is determined by the density and conformational arrangement of glycoconjugates, particularly when they are part of membrane receptors (Spicer \& Schulte, 1982).

A detailed study of lectin binding patterns to placentas in the cow or in other species with epitheliochorial placentation has not been reported. Definition of the glycoconjugate composition in the normal endometrium and chorion of the cow may lead to a better understanding of the process of implantation and placentation.

*Present address: Department of Pathology, National Zoological Park, Smithsonian Institution, Washington, D.C. 20008 , USA. 
This paper characterizes the carbohydrate composition of the bovine placenta through lectin binding patterns, with particular interest in glycoconjugate composition of apical cell membranes involved in the process of embryo attachment.

\section{Materials and Methods}

Tissues. Placentomes with adjacent interplacentomal tissue, obtained from an abattoir, were selected from four stages of pregnancy: $<40$ days, $80-100$ days, 150-180 days, and 270 days. Gestational age was estimated by fetal crownrump length (Roberts, 1986) and 2 caruncles from each of 3 animals were used for each stage of pregnancy. Chorion and endometrial epithelium were collected separately from animals $<40$ days pregnant, because trophoblastic attachment did not survive tissue handling. Endometrial epithelium was obtained from the uteri of 3 fetuses at $\approx 260-270$ days of gestation and from 3 non-pregnant cows during the luteal stage of the oestrous cycle.

Placentomes were perfused in situ with Bouin's solution and stored in Bouin's solution. All other tissues were fixed by immersion in Bouin's solution. Tissues were embedded in paraffin wax, sectioned at $7-9 \mu \mathrm{m}$, and placed on resincoated slides.

Lectins. The origins, sugar specifications, and inhibiting sugars (Sigma Chemical Co., St Louis, MO, USA) of the 13 biotinylated lectins (Vector Laboratories, Burlingame, CA, USA) used for this study are presented in Table 1. Lectins were used at the following concentrations: BSL, LCA, PNA, SBA and UEA at $10 \mu \mathrm{g} / \mathrm{ml} 0.01 \mathrm{~m}$-phosphatebuffered saline containing 0.001 M-Ca ${ }^{2+}$ (PBS) and ConA, DBA, PHA-E, PHA-L, PSA, RCA-1, sWGA and WGA at $5 \mu \mathrm{g} / \mathrm{ml}$ PBS.

Table 1. Lectins used on bovine chorion and endometrial epithelium and their binding specificities

\begin{tabular}{|c|c|c|c|}
\hline Lectin origin & Acronym & $\begin{array}{l}\text { Major } \\
\text { sugar specificity }\end{array}$ & $\begin{array}{l}\text { Inhibiting } \\
\text { sugar }\end{array}$ \\
\hline Bandeirea simplicifolia & BSA & D-Galactose & Lactose $0.5 \mathrm{M}$ \\
\hline Dolichos biflorus & DBA & D-GalNAc & D-GalNAc $0.2 \mathrm{M}$ \\
\hline Glycine max & SBA & D-GalNAc, D-Gal & D-GalNAc $0.2 \mathrm{M}$ \\
\hline Ricinus communis & RCA-1 & D-Gal & D-Gal $0.2 \mathrm{M}$ \\
\hline Phaseolus vulgaris & PHA-E & D-GalNAc & D-GalNAc $0.5 \mathrm{M}$ \\
\hline Phaseolus vulgaris & PHA-L & D-GalNAc & D-GalNAc $0.5 \mathrm{M}$ \\
\hline Arachis hypogea & PNA & Gal (1-3)GalNAc & Lactose $0.5 \mathrm{M}$ \\
\hline Concanavalia ensiformis & Con-A & D-Glc, D-Man & Mannose $0.5 \mathrm{M}$ \\
\hline Pisum sativum & PSA & D-Glc, D-Man & Mannose $1.0 \mathrm{M}$ \\
\hline Lens culinaris & LCA & D-GIc, D-Man & Mannose $0.5 \mathrm{M}$ \\
\hline Triticum vulgaris & WGA & $\begin{array}{l}(\beta-(1-4)-D-G l c N A c)_{2} \\
\text { NeuNAc }\end{array}$ & $\begin{array}{l}\text { GlcNAc } 0.5 \mathrm{M} \\
\text { NeuNAc } 0.5 \mathrm{M}\end{array}$ \\
\hline $\begin{array}{l}\text { Triticum vulgaris } \\
\text { (succinyl) }\end{array}$ & sWGA & $(\beta-(1-4)-D-G l c N A c)_{2}$ & GlcNAc $0.5 \mathrm{M}$ \\
\hline Ulex europaeus & UEA & L-Fucose & L-Fucose $0.2 \mathrm{M}$ \\
\hline
\end{tabular}

Lectin staining. Tissue sections were deparaffinized in xylene and rehydrated through graded dilutions of ethanol and PBS. Endogenous peroxidase activity was blocked by preincubation of tissues with $0.5 \%$ hydrogen peroxide in methanol for $15 \mathrm{~min}$ at room temperature, then washed in PBS. Tissue sections then were covered by lectin solutions and placed in a humid chamber for $1 \mathrm{~h}$ at room temperature. Two negative controls to confirm the specificity of staining included the omission of the lectin and preincubation of the lectin with the blocking sugar for 20 min at room temperature before incubation of the tissue. Tissues were washed 3 times in PBS, then covered with strepavidinperoxidase conjugate (Biogenex Laboratories, Dublin, CA, USA) for $20 \mathrm{~min}$ at room temperature. Following 3 PBS washes, the tissues were incubated in $0.05 \%$ diaminobenzadine in $0.05 \mathrm{M}$-T ris buffer with $1 \%$ hydrogen peroxide until a positive reaction was observed $(20-90 \mathrm{sec})$, then counterstained with Harris' haematoxylin. The intensity of lectin binding was subjectively scored from - (none) to ++++ (strongly positive) by one author (L.M.).

\section{Results}

\section{Lectin binding in the bovine chorion}

All 13 lectins bound to chorionic trophoblastic cells (Table 2), although the binding varied in pattern, in intensity, by cell type, by stage of pregnancy, and by region within the chorion. Representative patterns of lectin binding are presented in Fig. 1. 
Table 2. Lectin binding* to bovine chorionic surface

\begin{tabular}{lcccc}
\hline & \multirow{2}{*}{$\begin{array}{c}\text { Early } \\
\text { gestation } \\
\text { Lectin }\end{array}$} & \multicolumn{3}{c}{ Middle and late gestation $(>80$ days $)$} \\
\cline { 3 - 5 } & $(<40$ days $)$ & Villus & Arcade & Intercotyledonary \\
\hline BSL & ++ & + & ++ & ++ \\
DBA & + & $+l-$ & $+l-$ & ++ \\
SBA & +++ & ++ & ++ & +++ \\
RCA-1 & +++ & +++ & +++ & +++ \\
PHA-E & ++ & + & ++ & ++ \\
PHA-L & ++ & + & ++ & ++ \\
PNA & +++ & ++ & ++ & +++ \\
Con-A & + & + & + & + \\
PSA & ++ & ++ & ++ & ++ \\
LCA & +++ & ++ & ++ & ++ \\
sWGA & ++ & +++ & +++ & +++ \\
WGA & ++ & +++ & +++ & +++ \\
UEA & - & - & - & + \\
\end{tabular}

*Values separated by a slash indicate variation in intensity of binding in individual cells.

\section{Chorionic surface binding}

In early pregnancy ( $<40$ days), LCA, PNA, RCA and SBA bound with highest intensity to the apical surface of the trophoblastic cells (Table 2). Only RCA persisted in intensity through all stages of pregnancy, whereas PNA and SBA binding decreased slightly in the cotyledons in middle and late gestation, but remained strong in the intercotyledonary region. LCA decreased more dramatically in all parts of the chorion from approximately Day 80 until term. Six other lectins, BSL, PHA-E and PHA-L, PSA, sWGA and WGA, also bound strongly to the trophoblastic surface before Day 40 of gestation, but less strongly than LCA, PNA, RCA, and SBA. The intensity of surface binding of PHA-L, PHA-E, and BSL within cotyledons from Day 80 until term decreased, except in the arcade region, and intercotyledonary chorionic binding of these lectins remained strong. PSA bound strongly in all regions throughout gestation, whereas both sWGA and WGA binding in all regions increased later in gestation.

The patterns of lectin binding to the chorionic surface after Day 80 of gestation are presented in Table 2. Notable differences in lectin binding are the persistence of the intensity of binding of many lectins in arcade and intercotyledonary regions of the chorion (BSL, PHA-E, PHA-L, PSA) and the prominence of surface binding of SBA and PNA in intercotyledonary areas.

\section{Chorionic cytoplasmic binding}

Five lectins highlighted binucleate trophoblastic giant cells by intense cytoplasmic binding (DBA, PHA-L, PHA-E, PNA, and SBA) (Table 3). Four lectins (Con A, PSA, LCA, and BSL) bound more strongly to non-giant uninucleate trophoblastic cells than binucleated cells and therefore highlighted binucleated cells through lack of staining.

The most notable regional difference in uninucleate trophoblastic cell cytoplasmic staining was the great intensity of binding of 9 lectins (BSL, Con A, DBA, LCA, PNA, PSA, SBA, SWGA, WGA) in arcades of cotyledons and in the intercotyledonary chorion. For binucleated cells, PHA$\mathrm{L}$ and PHA-E staining was more intense in the intercotyledonary areas than within the cotyledon, and DBA binding varied greatly amongst individual binucleated cells in the intercotyledonary chorion (some cells were negative, some weakly positive, and some strongly positive). The pattern of binding within binucleate cell cytoplasm was usually diffuse and finely granular, except for patchy binding of RCA, Con A and WGA and polarized binding of SBA and PNA. Smaller binucleated cells stained more strongly than did larger ones for PSA, LCA and Con A, suggesting the progressive dilution of the binding carbohydrate moiety with cell enlargement. 

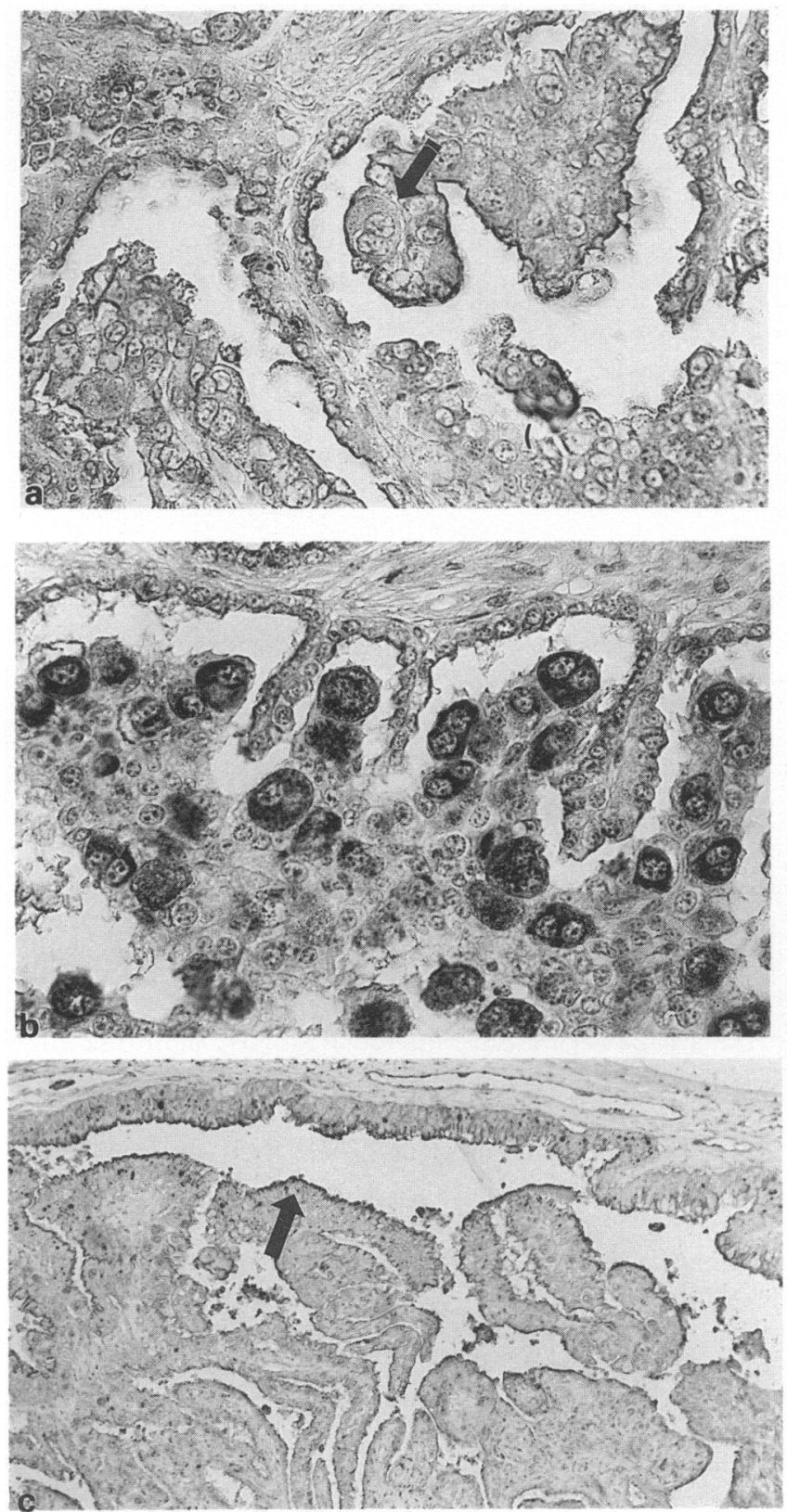

Fig. 1. Binding of (a) PNA lectin, (b) DBA lectin and (c) RCA-1 lectin to a section of the placentome of cows in the middle third of pregnancy. In (a) the pattern of chorionic and endometrial surface binding in combination with weak binucleate cell binding (arrow) is illustrated. In (b) there is strong binucleate trophoblastic cell staining. In (c), note the increase in intensity of binding to trophoblastic cell surfaces within arcades (arrow). $\times 250$.

\section{Miscellaneous placental binding}

The allantois bound all lectins, although PHA-E and PSA only bound weakly. All lectins except DBA and sWGA bound to allantoic stroma. UEA and to a lesser extent RCA and Con A bound to allantoic endothelium, and UEA bound strongly to trophoblastic cell basement membrane. 
Table 3. Intracellular lectin binding* to trophoblastic cells of cows $>80$ days pregnant

\begin{tabular}{|c|c|c|c|c|c|c|}
\hline \multirow[b]{2}{*}{ Lectin } & \multicolumn{3}{|c|}{ Binucleated cells } & \multicolumn{3}{|c|}{ Uninucleate cells } \\
\hline & Villus & Arcade & Intercotyledonary & Villus & Arcade & Intercotyledonary \\
\hline BSL & + & ++ & ++ & $+1-$ & ++ & ++ \\
\hline DBA & ++++ & ++++ & $++++1+1-$ & - & - & $+++1-$ \\
\hline SBA & ++ & $+t$ & ++ & $+1-$ & ++ & ++ \\
\hline RCA-I & + & ++ & ++ & + & ++ & + \\
\hline PHA-E & ++ & ++ & $+++1++$ & + & $+1++$ & $+1++$ \\
\hline PHA-L & +++ & +++ & ++++ & ++ & $+1++$ & $+1-$ \\
\hline PNA & +++ & +++ & +++ & $t+$ & $++1+++$ & +++ \\
\hline ConA & + & + & $+1-$ & $+1++$ & $++1+++$ & +++ \\
\hline PSA & $+1-$ & $+1-$ & $+1-$ & $++1+$ & +++ & +++ \\
\hline LCA & $++1+$ & $++1+$ & $++1+$ & $++1+$ & ++ & +++ \\
\hline sWGA & $+1-$ & $+1++$ & $+1++$ & $+1-$ & $+1-$ & $+1++$ \\
\hline WGA & $+1-$ & $+/++$ & $+1++$ & $+1++$ & $+1++$ & +++ \\
\hline UEA & - & - & - & - & - & - \\
\hline
\end{tabular}

*Values separated by a slash indicate variation between individual cell binding intensity.

\section{Lectin binding to endometrial epithelium}

Five lectins (BSL, DBA, PNA, WGA, sWGA) bound with more intensity to the surface of endometrial epithelial cells in early pregnant ( $<40$ days) cows than in non-pregnant animals (Table 4). The intensity of both surface and cytoplasmic binding in the caruncular epithelium decreased as gestation progressed, except for PNA and sWGA which bound with increasing intensity to cell surfaces later in gestation. Surface binding to fetal endometrium was patchy and always less intense than in adults. UEA binding was strong on non-pregnant endometrium, weak on early pregnancy, and notably absent from all later stages of pregnancy and fetal endometrium.

Table 4. Lectin binding* to luminal endometrial epithelium of cows

\begin{tabular}{|c|c|c|c|c|c|c|c|c|}
\hline \multirow[b]{3}{*}{ Lectin } & & & & & \multicolumn{4}{|c|}{ Pregnant } \\
\hline & \multicolumn{2}{|c|}{ Fetal } & \multicolumn{2}{|c|}{ Non-pregnant } & \multicolumn{2}{|c|}{$<40$ days } & \multicolumn{2}{|c|}{$>80$ days } \\
\hline & $\mathrm{CM}$ & Cyto & CM & Cyto & CM & Cyto & $\mathrm{CM}$ & Cyto \\
\hline BSL & ++ & + & + & ++ & +++ & ++ & + & $+1-$ \\
\hline DBA & + & $+1-$ & ++ & + & $+t+$ & $+t$ & ++ & - \\
\hline SBA & ++ & + & ++ & + & ++ & ++ & ++ & + \\
\hline RCA-1 & ++ & + & ++ & + & ++ & ++ & ++ & $+1-$ \\
\hline PHA-E & + & $+1-$ & +++ & ++ & +++ & + & + & + \\
\hline PHA-L & + & $+1-$ & +++ & ++ & +++ & ++ & + & + \\
\hline PNA & $+1-$ & - & + & - & ++ & ++ & +++ & ++ \\
\hline ConA & - & $+1-$ & + & ++ & + & $+t$ & $+1-$ & + \\
\hline PSA & - & $+1-$ & + & + & + & + & $+1-$ & + \\
\hline LCA & $+1-$ & $+1-$ & + & ++ & + & $+1-$ & $+1-$ & + \\
\hline sWGA & + & - & + & + & ++ & + & +++ & + \\
\hline WGA & + & $+1-$ & + & $+1-$ & +++ & + & $+t+$ & + \\
\hline UEA & - & - & + & $+t$ & + & + & - & - \\
\hline
\end{tabular}

$\mathrm{CM}=$ apical cell membrane binding; Cyto = cytoplasmic binding.

*Values separated by a slash indicate variation in intensity of binding in individual cells.

The binding of BSL, DBA, SBA, RCA, PNA, Con A, PSA and WGA to endometrial glands also was stronger in pregnant than in non-pregnant animals (Table 5). The intensity of binding continued to increase throughout gestation for RCA and PNA. The pattern of binding for the 
Table 5. Lectin binding* to bovine endometrial glandular epithelium

\begin{tabular}{|c|c|c|c|c|c|c|}
\hline \multirow[b]{2}{*}{ Lectin } & \multicolumn{2}{|c|}{ Non-pregnant } & \multicolumn{2}{|c|}{$\begin{array}{l}\text { Pregnant } \\
<40 \text { days }\end{array}$} & \multicolumn{2}{|c|}{$\begin{array}{l}\text { Pregnant } \\
>80 \text { days }\end{array}$} \\
\hline & $\mathrm{CM}$ & Cyto & $\mathrm{CM}$ & Cyto & $\mathrm{CM}$ & Cyto \\
\hline BSL & + & + & +++ & $++t$ & ++ & + \\
\hline DBA & + & - & +++ & ++ & - & ++ \\
\hline SBA & ++ & + & +++ & ++ & ++ & + \\
\hline RCA-1 & + & $+1-$ & ++ & + & +++ & ++ \\
\hline PHA-E & + & + & - & + & ++ & + \\
\hline PHA-L & ++ & + & +++ & + & ++ & + \\
\hline PNA & + & - & ++ & + & +++ & +++ \\
\hline ConA & - & + & - & ++ & ++ & + \\
\hline PSA & - & + & - & + & + & + \\
\hline LCA & + & + & - & + & $+t$ & + \\
\hline sWGA & & & ++ & + & ++ & + \\
\hline WGA & + & $+1-$ & ++ & + & +++ & ++ \\
\hline UEA & - & - & - & - & - & - \\
\hline
\end{tabular}

$\mathrm{CM}=$ apical cell membrane binding; Cyto = cytoplasmic binding.

*Values separated by a slash indicate variation in intensity of binding in individual cells.

majority of lectins was coarse and granular, and located within the apical cytoplasm. A parallel pattern of lectin binding was seen in the glandular luminal fluid.

BSL, SBA, RCA and PHA-L bound to carbohydrate moieties in endometrial and myometrial microvascular endothelium, UEA bound to all endothelia, Con A, LCA, RCA and PSA bound to endometrial stromal cells, and DBA, RCA, PHA-L, PNA, Con A, PSA and WGA highlighted leucocytes within the endometrium. Glycoconjugates within leucocytes were most strongly bound by PHA-L and PNA.

\section{Effect of blocking sugars}

The blocking sugars listed in Table 1 effectively prohibited lectin binding to endometrial epithelium and to chorion with a few notable exceptions. LCA was partly blocked by D-methylmannose, but completely blocked by mannose. For several lectins (RCA, Con A, PSA and sWGA) the sugars effectively blocked all binding within the placentome, but incompletely blocked arcade binding at the concentrations used. WGA binding was inhibited by $N$-acetylneuraminic acid in all regions except the arcades where weak binding persisted; however, WGA surface binding was not inhibited by $N$-acetylglucosamine. $N$-acetylgalactosamine $(0.5 \mathrm{M})$ was required to block the binding of PHA-E and PHA-L.

\section{Discussion}

The high reactivity of the chorion and endometrial epithelium of the cow to many lectins is consistent with the knowledge that glycoproteins are major components of cell-cell attachment and tissue remodelling processes (Edelman, 1984, 1986; Feizi, 1985). The higher intensity binding of many lectins in the arcade region of the placentomes and in the intercotyledonary chorion may indicate a concentration of cell adhesion molecules in regions of epitheliochorial placentas which do not have the anchoring benefit of crypt and villus interdigitation.

Intense binding of three lectins, WGA, sWGA and PNA, to both the endometrial and chorionic surfaces in early pregnancy, implies that both sialic acid and $N$-acetylglucosamyl moieties are present on these surfaces. The epidermal growth factor receptor, which binds WGA (Hock \& 
Hollenberg, 1980), contains sialic acid and $N$-acetylglucosamine residues (Childs et al., 1984) and the cell adhesion molecule, CAM-105, has been reported to bind WGA (Svalander et al., 1987). The binding of PNA, as well as many other galactosyl-binding lectins (BSL, SBA, RCA, PHA-E, PHAL) to the trophoblastic cell surface suggests an important role of this carbohydrate in chorionic attachment and function. Binucleate cell cytoplasm also intensely bound lectins which were specific for galactosyl residues; binucleate cells may contribute to the fetal-maternal interface through migration and exocytosis (Wooding, 1982; King et al., 1982). Endogenous lectins in the human placenta, which are thought to be involved in protein-carbohydrate interactions with glycoconjugates of the placental membranes (Paroutaud et al., 1987; Hirabayashi et al., 1987), include a $\beta$-D-galactoside lectin. Abundant galactosyl binding sites on bovine placentomes may be important for the formation and maintenance of the chorionic-endometrial interface through interaction with similar endogenous lectins.

The intensity of binding of many lectins to binucleate trophoblastic cells, particularly DBA, PHA-L, PHA-E and PNA, indicates a high glycoconjugate content of these cells. The high glycoconjugate content of bovine and ovine binucleate trophoblastic cells has been noted previously with morphological (Boshier, 1969; Boshier \& Holloway, 1977), histochemical (Wimsatt, 1951; Wooding, 1980; Wooding \& Wathes, 1980; Wooding et al., 1980; Lee et al., 1985), and immunocytochemical (Lee et al., 1986c) techniques. Our results also support findings that demonstrated staining variation among binucleated trophoblastic cells, suggesting that more than one population of binucleated cells may exist (Greenstein et al., 1958; Boshier \& Holloway, 1977; Wooding \& Wathes, 1980; Watkins \& Reddy, 1980; Lee et al., 1985, 1986a, b, c, d).

Several lectins were notable as excellent markers of endometrial epithelial polarization (via strong apical surface staining) and of endometrial glandular activity: BSL, DBA, PHA-L, PHA-E, PNA, SBA, sWGA and WGA. Changes in the endometrial glands in pregnancy were similar to but not identical with the changes in lectin binding pattern of the luminal epithelium. The greater intensity of lectin binding in endometrial glands of pregnant cows, than of mid-cycle cows, and the pattern of that binding (apical cytoplasm and luminal contents) may reflect a qualitative change in secretory activity in the uterus due to the presence of a conceptus, rather than an effect of progesterone alone.

Several pregnancy-associated changes in lectin binding patterns on the endometrium noted in this study were very similar to those reported for other species. An increase in binding of WGA has been found in horses (Whyte \& Allen, 1985), mice (Lee et al., 1983; Damjanov \& Lee, 1986), sheep and pigs (Whyte \& Robson, 1984), whereas no change in WGA binding in pregnancy occurred in women (Lee \& Damjanov, 1985). Loss of UEA binding in pregnancy has been noted for mouse and human endometria (Lee et al., 1983; Lee \& Damjanov, 1985; Damjanov \& Lee, 1986), but this contrasts with observation of local increases in L-fucose receptors in pregnant endometrium of horses (Whyte \& Allen, 1985). Otherwise, changes in binding intensity in humans (Lee \& Damjanov, 1985) closely paralleled those found in this study for SBA, PNA, PHA-E, LCA and Con A. Con A binding sites have been reported to decrease at pregnancy in mice (Enders $\&$ Schlafke, 1974), but do not change in sheep (Guillomot et al., 1982), as was found in cows in this study.

Comparison of results from this study and other reports also demonstrates species differences in lectin binding patterns to the chorion (Whyte et al., 1978; Guillomot et al., 1982; Lee et al., 1983; Lee \& Damjanov, 1984; Whyte \& Robson, 1984; Chavez \& Anderson, 1985; Chavez, 1986; Kimber, 1986; Svalander et al., 1987; Loke \& Burland, 1988). The variation in lectin binding patterns among species emphasizes the need to determine normal patterns for a species before using lectins as markers of pathological change. The variations seen within species among investigators may relate to variations in tissue handling or tissue type (stage of cycle or of gestation). Variations in lectin binding patterns for different lectins with the same carbohydrate specificity have also been reported by other investigators (Hsu \& Ree, 1983; Lee \& Damjanov, 1984). These results emphasize the need to test each lectin for its unique binding pattern on each tissue. 
The lectin binding patterns to glycoconjugates of the bovine chorion and endometrium determined in this study demonstrate many of the unique characteristics of different regions and cell types within the placenta and between the non-pregnant and pregnant endometrium.

This work was supported by a grant from U.S.D.A. Animal Health and Disease Program.

\section{References}

Alroy, J., Szoka, F.C., Heaney, J.A. \& Ucci, A.A. (1982) Lectins as a probe for carbohydrate residues in nonneoplastic urothelium of human urinary bladder. $J$. Urol. 128, 189-193.

Alroy, J., Ucci, A.A., Goyal, V. \& Woods, W. (1986) Lectin histochemistry of glycolipid storage diseases on frozen and paraffin-embedded tissue sections. $J$. Histochem. Cytochem. 34, 501-505.

Alroy, J., Ucci, A.A. \& Pereira, E.A. (1988) Lectins: Histochemical probes for specific carbohydrate residues. In Advances In Immunohistochemistry, pp. 67-88. Ed. R. A. Delellis. Year Book Medical, Chicago.

Boshier, D.P. (1969) A histological and histochemical examination of implantation and early placentome formation in sheep. J. Reprod. Fert. 19, 51-61.

Boshier, D.P. \& Holloway, H. (1977) The sheep trophoblast and placental function: an ultrastructural study. J. Anat. 124, 287-298.

Brandley, B.K. \& Schnaar, R.L. (1986) Cell-surface carbohydrates in cell recognition and response. $J$. Leukocyte Biol. 40, 97-111.

Castagnaro, M., Alroy, J., Ucci, A.A. \& Glew, R.G. (1987) Lectin histochemistry and ultrastructure of feline kidneys from six different storage diseases. Virchows Arch. B54, 16-26.

Chavez, D.J. (1986) Cell surface of mouse blastocysts at the trophectoderm-uterine interface during the adhesive stage of implantation. Am. J. Anat. 176, 153-158.

Chavez, D.J. \& Anderson, T.L. (1985) The glycocalyx of the mouse uterine luminal epithelium during estrus, early pregnancy, the peri-implantation period, and delayed implantation. I Acquisition of ricinus communis I binding sites during pregnancy. Biol. Reprod. 32, 1135-1142.

Childs, R.A., Gregorious, M., Scudder, P., Thorpe, S.J., Rees, A.R. \& Feizi, T. (1984) Blood group-active carbohydrate chains on the receptor for epidermal growth factor of A431 cells. EMBO J. 3, 2227-2233.

Damjanov, I. \& Lee, M.C. (1986) Pregnancy-related changes in murine and human endometrium revealed by differential binding of fluoresceinated lectins. In Pregnancy Proteins in Animals, pp. 177-183. Ed. J. Hau. Walter de Gruyter \& Co., Berlin.

Damsky, C.H., Knudsen, K.A. \& Buck, C.A. (1982) Integral membrane glycoproteins related to cellsubstratum adhesion in mammalian cells. $J$. Cell Biochem. 18, 1-13.

Edelman, G.M. (1984) Expression of cell adhesion molecules during embryogenesis and regeneration. Expl Cell Res. 161, 1-16.

Edelman, G.M. (1986) Cell adhesion molecules in the regulation of animal form and tissue pattern. Ann. Rev. Cell Biol. 2, 81-116.
Enders, A.C. \& Schlafke, S. (1974) Surface coats of the mouse blastocyst and uterus during the preimplantation period. Anat. Rec. 180, 31-46.

Feizi, T. (1985) Demonstration by monoclonal antibodies that carbohydrate structures of glycoproteins and glycolipids are onco-developmental antigens. Nature, Lond. 314, 53-57.

Greenstein, J.S., Murray, R.W. \& Foley, R.C. (1958) Observations on the morphogenesis and histochemistry of the bovine preattachment placenta between 16 and 33 days of gestation. Anat. Rec. 132, 321-341.

Guillomot, M., Flechon, J.E. \& Wintenberger-Torrès, S. (1982) Cytochemical studies of uterine and trophoblastic surface coats during blastocyst attachment in the ewe. J. Reprod. Fert. 65, 1-8.

Hirabayashi, J., Kawasaki, H., Suzuki, K. \& Kasai, K. (1987) Further characterization and structural studies on human placenta lectin. J. Biochem. (Tokyo) 101, 987-995.

Hock, R.A. \& Hollenberg, M.D. (1980) Characterization of the receptor for epidermal growth factorUrgastrone in human placenta membranes. J. biol. Chem. 255, 10731-10736.

Hsu, S.M. \& Ree, H.J. (1983) Histochemical studies on lectin binding in reactive lymphoid tissues. J. Histochem. Cytochem. 31, 538-546.

Kimber, S.J. (1986) Distribution of lectin receptors in postimplantation mouse embryos at 6-8 days gestation. Am. J. Anat. 177, 203-219.

King, G.J., Atkinson, B.A. \& Robertson, H.A. (1982) Implantation and early placentation in domestic ungulates. J. Reprod. Fert., Suppl. 31, 17-30.

Knudsen, K.A., Rao, P.E., Damsky, C.H. \& Buck, C.A. (1981) Membrane glycoproteins involved in cellsubstratum adhesion. Proc. natn. Acad. Sci. USA 78, 6071-6075.

Laitinen, L., Virtanen, I. \& Saxen, L. (1987) Changes in the glycosylation pattern during embryonic development of mouse kidney as revealed with lectin conjugates. J. Histochem. Cytochem. 35, 55-65.

Lee, C.S., Gogolin-Ewens, K., White, T.R. \& Brandon, M.R. (1985) Studies on the distribution of binucleate cells in the placenta of the sheep with a monocional antibody SBU-3. J. Anat. 140, 565-576.

Lee, C.S., Wooding, F.B. \& Brandon, M.R. (1986a) Light and electron microscope immunocytochemical studies on the role of binucleate cells in villus growth in goat placentomes. J. Submicrosc. Cytol. 18, 661-672.

Lee, C.S., Wooding, F.B.P. \& Brandon, M.R. (1986b) Ultrastructural immunogold investigation of the function and diversity of binucleate cells in the ovine placenta using a monoclonal antibody. Placenta 7, 494-504. 
Lee, C.S., Wooding, F.B.P. \& Brandon, M.R. (1986c) Immunogold co-locatization of ovine placental lactogen and the antigen recognized by the SBU-3 monoclonal antibody in sheep placental granules. $J$. Reprod. Fert. 78, 653-662.

Lee, C.S., Gogolin-Ewens, K. \& Brandon, M.R. (1986d) Comparative studies on the distribution of binucleate cells in the placentae of the deer and cow using the monoclonal antibody. SBU-3. J. Anat. 147, 163-179.

Lee, M.C. \& Damjanov, I. (1984) Lectin histochemistry of human placenta. Differentiation 28, 123-128.

Lee, M.C. \& Damjanov, I. (1985) Pregnancy-related changes in the human endometrium revealed by lectin histochemistry. Histochemistry 82, 275-280.

Lee, M.C., Wu, T.C., Wan, Y.J. \& Damjanov, I. (1983) Pregnancy-related changes in the mouse oviduct and uterus revealed by differential binding of fluoresceinated lectins. Histochemistry 79, 365-375.

Loke, Y.W. \& Burland, K. (1988) Human trophoblast cells cultured in modified medium and supported by extracellular matrix. Placenta 9, 173-182.

Orgad, U., Alroy, J., Ucci, A.A. \& Merk, F.B. (1984) Histochemical studies of epithelial cell glycoconjugates in atrophic, metaplastic, hyperplastic, and neoplastic canine prostate. Lab. Invest. 50, 294-302.

Paroutaud, P., Levi, G., Teichberg, V.I. \& Strosberg, A.D. (1987) Extensive amino acid sequence homologies between animal lectins. Proc. natn. Acad. Sci. USA 84, 6345-6348.

Richa, J., Damsky, C.H., Buck, A., Knowles, B.B. \& Solter, D. (1985) Cell surface glycoproteins mediate compaction, trophoblast attachment, and endoderm formation during early mouse development. Devl Biol. 108, 513-521.

Roberts, S.J. (1986) Veterinary Obstetrics and Genital Diseases. Theriogenology, p. 19. S. J. Roberts, Woodstock, VT.

Spicer, S.S. \& Schulte, B.A. (1982) Identification of cell surface constituents. Lab. Invest. 47, 2-4.
Svalander, P.C., Odin, P., Nilson, B.O. \& Obrink, B. (1987) Trophectoderm surface expression of the cell adhesion molecule cell-CAM 105 on rat blastocysts. Development 100, 653-660.

Watkins, W.B. \& Reddy, S. (1980) Ovine placental lactogen in the cotyledonary and intercotyledonary placenta of the ewe. J. Reprod. Fert. 58, 411-414.

Whyte, A. \& Allen, W.R. (1985) Equine endometrium at pre-implantation stages of pregnancy has specific glycosylated regions. Placenta 6, 537-542.

Whyte, A. \& Robson, T. (1984) Saccharides localized by fluorescent lectins on trophectoderm and endometrium prior to implantation in pigs, sheep and equids. Placenta 5, 533-540.

Whyte, A., Loke, Y.W. \& Stoddart, R.W. (1978) Saccharide distribution in human trophoblast demonstrated using fluorescein-labelled lectins. Histochem. J. 10, 417-423.

Wimsatt, W.A. (1951) Observations of the morphogenesis, cytochemistry, and significance of the binucleate giant cells of the placenta of ruminants. Am. J. Anat. 89, 233-282.

Wooding, F.B.P. (1980) Electron microscopic locatization of binucleate cells in the sheep placenta using phosphotungstic acid. Biol. Reprod. 22, 357-365.

Wooding, F.B.P. (1982) The role of the binucleate cell in ruminant placental structure. J. Reprod. Fert. 31, 31-39.

Wooding, F.B.P. \& Wathes, D.C. (1980) Binucleate cell migration in the bovine placentome. J. Reprod. Fert. $59,425-430$.

Wooding, F.B.P., Chambers, C.G., Perry, J.S., George, M. \& Heap, R.B. (1980) Migration of binucleate cells in the sheep placenta during normal pregnancy. Anat. Embryol. 158, 361-370.

Received 13 February 1989 